\title{
Representation of Hijab Muslim Women as Seen in American Advertisements: Ability, Egalitarianism, and Resistance
}

DOI 10.18196/AlIJS.2020.0110.1-21

\section{MOONA MAGHFIRAH}

Interdisciplinary Islamic Studies UIN Sunan Kalijaga Yogyakarta

Corespondence Email: Maghfirahmoona96@gmail.com

\begin{abstract}
Since Muslim women fashion has risen in the world, many companies are showing Muslim women who wear hijab in their advertisements, including American brands advertisements. They are Nike, American Eagle, Covergirl, Fenty Beauty, and GAP. This case is important to be discussed because it is the opposite. America is a major country that is facing Islamophobia in which the hijab Muslim woman is seen as an agent representing the identity of Islam. Therefore, the study aims to reveal the meaning of the Muslim women model in these advertisements. The method used in this study is a qualitative descriptive method and applies Roland Barthes semiotic theory and religiofication of commodities theory. This article found the meanings of Muslim women models refer to the current phenomena of Muslim women life such as the modern beauty and lifestyle of Muslim women, and the freedom in showing their status and skill, and the diversity in the representation of women beauty. Three myths (ideologies) implied in this article are a deconstruction of a negative stereotype of Muslim women in America, beauty standard, and egalitarianism values. Thus, this article argues that the advertisement is an underground movement of Muslim women as their resistance to negative stigmas in American society by expressing their identities, ability, and egalitarianism values.

Keywords: Muslim Women, American Advertisement, Resistance.
\end{abstract}

\section{ABSTRAK}

Sejak berkembangnya fashion Muslim women di dunia, ada banyak perusahaan perusahaan yang menayangkan perempuan Muslim berhijab pada iklan mereka, salah satu contohnya iklan pada produk Amerika. Iklan-iklan tersebut ialah Nike, 
American Eagle, Fenty Beauty, Covergirl,dan GAP. Fenomena ini layak untuk dikaji, karena terdapat sesuatu yang sangat bersifat kontradiktif. Amerika dikenal sebagai negara utama yang menghadapi problem Islamofobia, sedangkan perempuan Muslim berhijab merupakan agen yang menunjukan identitas agama Islam. Oleh karena itu, artikel ini hendak mengungkap makna dari model Muslim women pada iklaniklan produk Amerika tersebut. Metode yang digunakan adalah kualitatif deskriptif dan menerapkan teori semiotika Roland Barthes dan teori religiofikasi komoditas. Artikel ini menemukan bahwa makna perempuan Muslim berhijab dalam iklan tersebut merujuk kepada fenomena kehidupan perempuan Muslim saat ini. Seperti, standar kecantikan dan gaya hidup para Muslim women, kebebasan dalam berekspresi dan menampilkan kemampuan Muslim women, serta diversitas representasi kecantikan pada perempuan. Terdapat tiga mitos (ideologi) yang ditemukan pada artikel ini adalah bentuk resistensi dan dekonstruksi stereotip negatif terhadap perempuan Muslim berhijab di Amerika, standar kecantikan, dan nilainilai egalitarianisme. Demikian, artikel ini berargumen bahwa iklan merupakan sebuah gerakan bawah tanah bagi para perempuan Muslim sebagai bentuk resistensi mereka terhadap stigma-stigma negatif yang ada di masyarakat Amerika, dengan cara mengekspresikan identitas, abilitas, dan nilai-nilai egalitarianisme.

Kata Kunci: Iklan-Iklan Amerika, Perempuan Muslim dan Resistense

\section{INTRODUCTION}

In the globalization era, the mass media has an important role in conveying information to the public. The media can build public opinions which ultimately become one of the factors in the change process. Borrowing $C$. Wright Mills' opinion who argued that primary experience had been replaced by secondary communication, such as mass media. ${ }^{1}$ The media plays a substantial role in transforming the social order into a mass society. Dealing with the mass media, a communication expert, Abdul Muis, also believes that the function of the mass media is to maintain the identification of community members with values and symbols for the community. Noam Chomsky also discussed in his book and documentary, entitled "Manufacturing Consent", that the media has its way of operating and trying to control public thought. 2 Media content certainly has a message to be conveyed to the public which has been designed in such a way by the product owner. The messages are designed with symbols and choices of interface that affect the meaning of the symbols so that they are easily captured by the recipient of the message. Media content is the result of a reality construction using language as a basic tool. ${ }^{3}$ As revealed by Pamela J. Shoemaker and Stephen D. Reese (2013) in Mediating The Message: Theories of Influence on Mass Media Content, various factors influence media content, one of them is media ideology. The 
function and position of the ideology is built to maintain or utter a new perspective adjusting to the status quo in the community. Furthermore, through media technology, Chaney argued advertising plays a major role in establishing the image and taste culture, through the onslaught of advertisements that offer a lifestyle visually. ${ }^{4}$ Similarly, Althusser stated that advertising as part of the culture industry which plays a role as an apparatus for constructing meaning by infusing value to a product. ${ }^{5}$ In advertising, language is used as a means of exchanging messages and a medium of communication between producers and consumers. Through visual images, words, and text, an advertisement produces signs containing signifier and signified which then form denotative - explicit or literal meanings - and connotative - implicit meanings or that involve emotions, feelings, and culture. Advertisement can also be interpreted from various perspectives because humans have a huge capacity in looking at things in a variety of ways. ${ }^{6}$ In this case, some famed American advertisements also carry an implicit message that is necessary to review and look at the way they are framing the packaging. This problem departs from the findings of Muslim women who are shown in the visual advertisement of products coming from the United States. As seen from the period time, this phenomenon appears along with the increasing Muslim population in their countries. The Pew Article Center study estimates that the Muslim population in America has expanded greatly in the last decade. Of the 326 million Americans, 3.45 million are Muslims of various ages living in America in $2017 .{ }^{7}$ This case has seemed quite phenomenal, especially after the world was shocked by the September 11, 2001 WTC tragedy. Along with the increasing Muslim population in the world and even in America itself, this has also become one of the factors of interest in the number of Muslim women to start stylish with the current Muslim fashion trends, even worldwide. This is proven by the emergence of Indonesian designers as representatives to present the hijab for the first time at an America Fashion Mode event, Couture Fashion Week (CFW), New York. They are Zaskia Sungkar, Dian Pelangi, and Barli Asmara. Indonesian Ulama' living in New York, Shamsi Ali, in his interview, claimed that representatives of three Indonesian designers to promote the hijab America had opened the opportunity to influence the development of hijab (Islamic hijab) fashion and spread Islam in America ${ }^{8}$, even though the event was held in America, which was under the hegemony of a president who is considered to be 'Anti-Islam', Donald Trump. Precisely, the case of the proliferation of Muslim women trends has also attracted the 
attention of American companies to take part in promoting and marketing products using the attribute 'hijabed woman'.

Five big American industrial products that use Muslim women who wear the hijab as advertising models and brand ambassadors. First, Nike, a manufacturer of American apparel, shoes, and sports equipment, which is one of the largest industries in the world, is located in Oregon, USA. Second, American Eagle is a manufacturer of jeans and American lifestyle accessories based in Pennsylvania, USA. Third, Fenty Beauty which is a cosmetics manufacturersponsored by a famous singer, Rihanna, under the auspices of Kendo Holdings, San Francisco, USA. Fourth, Covergirl is an American cosmetics brand manufacturer based in Maryland, USA. Finally, GAP, an American public company that is active in the retail industry, including fashion. GAP is headquartered in California, USA. The five advertisements were released at the end of 2016 up to the end of 2017 where the period time is the beginning of Donald Trump's leadership.

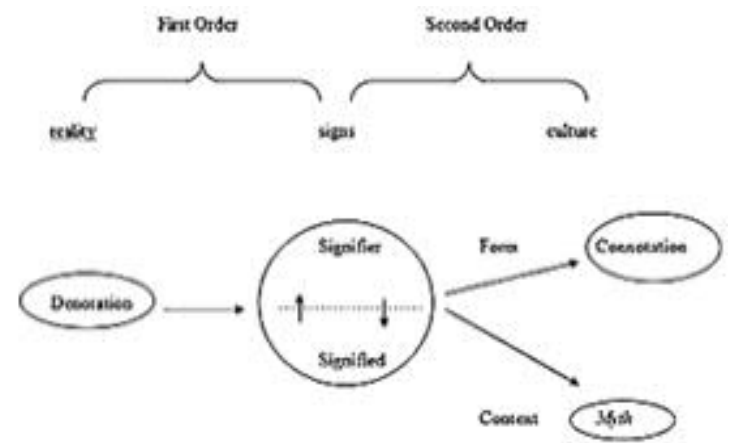

Picture 1. Scheme of Roland Barthes Semiotic

It is not a problem if a Muslim woman wearing a hijab is shown in an advertisement where a Muslim majority country lives. Whereas, it is engaging when it appears in several American industrial advertisements. Accordingly, the above phenomenon is an interesting fact to explore further. The problem is two conflicting things here, which are related to the encounter between hijab Muslim women and American media. Then the question arises as to what representation is contained in the depiction of Muslim women models in American advertisements and what is the meaning beyond it? Therefore, the purpose of this article is to interpret the depiction of the hijab Muslim women symbols in American advertisements and then uncover the meaning behind it by employing semiotic analysis. The type of this article is 
the qualitative analysis of semiotics, structural Roland Barthes. Roland Barthes developed a semiotic system which he used as the key to his analysis. He used the term 'order of signification'. In the Barthes concept, the order of signification means the study of the meaning of symbols in language or signs. Barthes has three stages to break the sign on the media: denotation, connotation, and myth. (see picture 1-ed)

In the concept of Barthes ${ }^{9}$, the above scheme explains the first order signification, namely the relationship between the signifier and the signified as external reality. As pointed from Saussure semiotic theory, the signifier is the material aspect, for instance, a physical object. Meanwhile, the signified is a mental concept or idea and meaning conveyed by the signifier. Barthes called it 'denotation' which means the most obvious sign meaning. Denotation is described as literal, clear, or plausible meaning. In other words, denotation is what an image shows and is immediately visible, rather than an assumption made by a reader about the picture. On the contrary, the connotation is the second order of signification of this concept. This connotation occurs when signs come in contact with the emotions or feelings of readers and their cultural values. The meaning of connotation is subjective. Therefore, denotation is simply what is symbolized by a sign of an object, while the connotation can be said as a meaning that contains emotions or feelings believed by someone about an image. Briefly, the connotative can be a figurative meaning of the denotation itself or not the real meaning. The myth itself is an ideology that reflects the sign through certain cultural glasses. ${ }^{10}$

Barthes' semiotic framework becomes a knife of analysis to uncover the meaning of the symbols of the Muslim women model in the American advertisement. As Roland Barthes defines that semiotics is a branch of science that analyzes the meaning of symbols and signs as representations of something that also refers to human life, or simply about how humanity signifies something. ${ }^{11}$ Every aspect of life can be constructed as a trust in society which will become a way of thinking or ideology. Thus, the main purpose of using Roland Barthes's semiotic theory is to criticize ideologies in a pop culture or mass culture. ${ }^{12}$

By employing Roland Barthes's semiotics, this article focuses on the phenomena that escape general attention about the meaning beyond the representation of hijab Muslim women in American advertisements. Many previous studies concentrated on Muslim women on media, but those researches were still rare focusing on how hijab Muslim women represented in western 
advertisements. For this reason, this article considers to fill this gap by analyzing the hijab Muslim women in five American advertisements and contributes to academic discussion associated with the positive correlation between Muslim women representation and American media. Based on reading some literature and exploring the data, this article indicated that there is significantly different Muslim women representation from previous western media. These five American advertisements have tried to go with the flow of the current hijab Muslim women lifestyle as well as the demand for race equality. As a result, this article argues that the existence of advertisement is an underground movement of hijab Muslim women as their resistance to negative stigmas in American society by expressing their identities, ability, and egalitarianism values.

\section{DISCUSSION}

\section{The Face of Hijab Muslim Women in American}

After the September $11^{\text {th }}$ attacks on the World Trade Center, hijab Muslim women get antagonistic attitude from some non-Muslim Americans. They have been the ones who often get the discrimination and prejudice in America, because of their religious identity. In 2019, Pew Research Centre estimated that $82 \%$ of American adults, acknowledged Muslims, are discriminated against a lot, especially veiled Muslim women. ${ }^{13}$ As examined by the Federal Bureau of Investigation (FBI), there are various violence they get as a victim of hatred, for instance, an insult, a harassment, and a crime. ${ }^{14}$ Moreover, the latest incidents reported the number of veiled Muslim women were intentionally harmed. They get some violent actions, such as some American pull their hijab in the street, pushed them to the train, punch and kick them out of the bus, and attack them while picking their children home from school

Living to be a hijab Muslim woman in America is quite troublesome. This position places them in what the Canadian Government defines as "Clearly Visible Minorities,". In contrast to the appearance of a Muslim man in America who is not necessarily identified as an Islam believer, a Muslim woman who wears a hijab will be directly identified with Islam. Hijab will usually give a negative impact to the wearer, in case of the target of discrimination. Jim Everett et al (2014), in Covered in Stigma? The Impact of Differing Levels of Islamic Head-covering on Explicit and Implicit Biases towards Muslim Women states that women who wear the hijab will tend to be more often targeted and accept the burden of discrimination because they are among the most 
visible parts of Muslims to be stigmatized. ${ }^{15}$ In consequence, hijab Muslim women also often face problems in having a job just because of the use of the hijab. Eman Abdelhadi' research found the hijab in America have a negative context with a job field, since the likelihood of being accepted into a job is lower compared to women who do not wear the hijab. ${ }^{16}$ Sandhya Somashekhar, a Washington Post reporter, wrote the story on August 29, 2005, "The hijab is currently a point of controversy related to women's human rights, religious extremism, and terrorism". A symbol by some points of view is more on Islamic radicals. ${ }^{17}$

This context seems real when viewed from American media that highlights the lives of the Afghan people. By using the image of pressures on Muslim women, the imperialistic policy, through the American invasion of Afghanistan, is true. At the time when American soldiers and journalists entered Afghanistan, they discovered the terrible conditions experienced by women under the Taliban regime. This situation further strengthens the stigma and perception that Muslim women are objects and even victims. Afterward, the tragedy of the September 11, 2001 WTC attack, Afghanistan became the initial focus for American society to pay attention to hijab Muslim women in the "Islamic" community. The majority of women living in Afghanistan wear burqa, clothes that cover the entire body from head to toe, and face coverings. Not surprisingly, some American society assumed hijab and burqa are a symbol of emphasis for Muslim women. ${ }^{18}$

Historically, the negative stigma against hijab Muslim women has been shown since a long time ago. Zeni in Muslim Women and the Politics of Representation examines the politics of representation of hijab Muslim women in colonial-era literature and texts in Western libraries. The results of his article found that the knowledge built in literature and text has created the image of hijab Muslim women as oppressed and weak. ${ }^{19}$ In Hijabs and Daggers: $A$ Century of National Geographic Representation of the Arab World, Linda Streets also revealed that the icons in the magazine for many years tend to display the image of underdeveloped Muslim women, and other negative stereotypes. $^{20}$

The antagonistic attitude also spreads to the Western media space. The news media, both print and online, stated that fundamentalism in Islam has increased the oppression of women. Journalists are more inclined to tell stories about hijab Muslim women living in Muslim countries and the Middle East by emphasizing the theme of violating women's rights, gender inequal- 
ity, and oppression. Scholars ${ }^{21}$ have examined several Western print and online media points out that the West often spreads sexist perceptions towards hijab Muslim women. The news media, both print and online, stated massively that fundamentalism in Islam has increased the oppression of women. This issue eventually spreads in western society, especially in America. As observed by Michelle Byng in 72 articles from the New York Times and the Washington Post published between January 2004 and December 2006, both newspapers represented the hijab as a sign of Islamic violence and radicalism. ${ }^{22}$

Consequently, Muslim women are presented as inferior and marginal human beings. In the end, the power and hegemony of the media greatly influence and control people's attitudes in viewing an issue related to Muslims. The media has very broad access to knowledge and forms a definition of political and social meaning about Muslims to the audience. ${ }^{23}$ This can be seen from the first image that comes to people's minds about hijab Muslim women is those who are restricted and isolated because of their gender, racial, cultural, and even religious identity.

\section{Interpretation of Hijab Muslim Women Model in American Brands Advertisements}

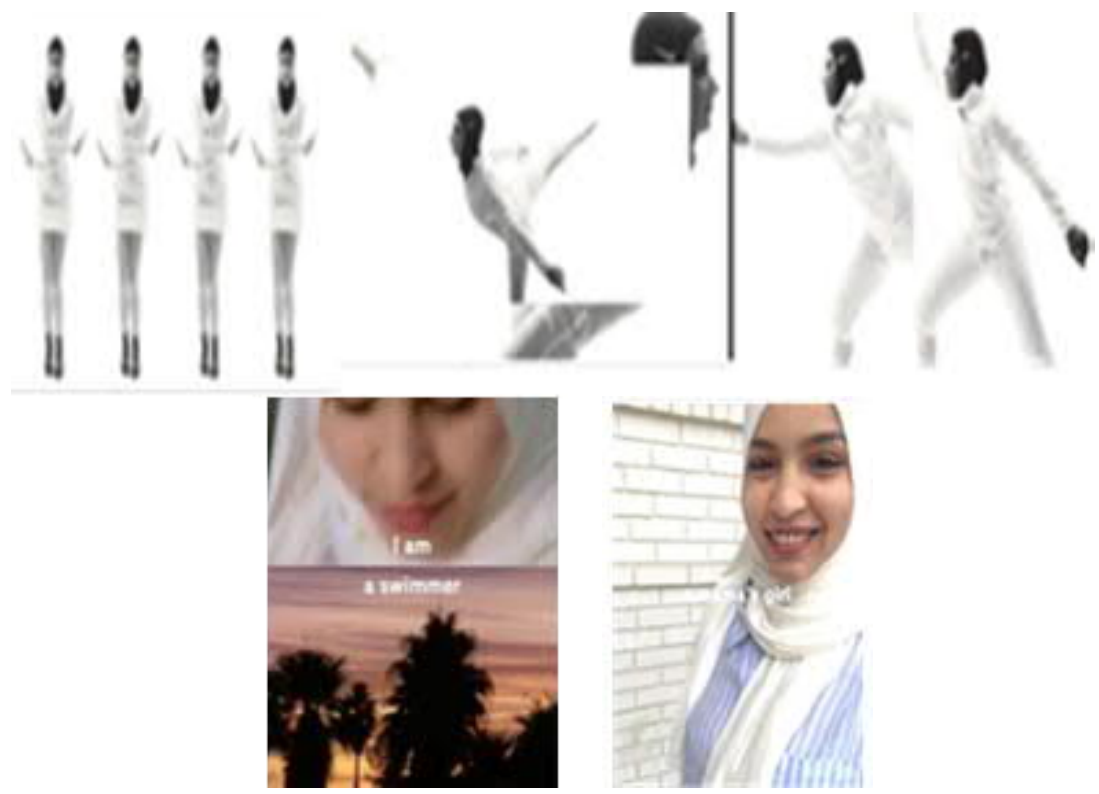

Picture 2: Nike Pro Hijab and GAP 
This case refers to two very contradictory things; the hijab Muslim women are agents representing Islamic identity and America that has a problem of Islamophobia. The meanings of the representation of the hijab Muslim women model tend to contain issues that are alluding to hijab Muslim women life. Such as the late popularity of Muslim women, the reconstruction of beauty standards, modern Muslim women lifestyle, and freedom of rights.

DENOTATION MEANING: The sign 1 are three women wearing hijab and playing a role like sports activities. First, an athlete woman is jumping-skipping. Second, an athlete woman is playing skating on one foot. Third, athlete woman is playing fencing. Besides, the next picture also depicts a woman wearing a white headscarf and breaking her smile. There is a caption in the image, i.e. 'I am swimmer' dan a mama's girl.

CONNOTATION MEANING: Expression of freedom and ability of hijab Muslim women

The three hijab Muslim women in the Nike advertisement are international athletes. They are Zeina Nassar as a boxer, Ibjtihad Muhammad as a fencing athlete, and Zahra Lari as an ice ski athlete. Meanwhile, a hijab Muslim woman in a GAP advertisement named Hbyutalla who is a mother, but also a swimming athlete. Therefore, the screenshots in this advertisement have the connotation meaning that hijab Muslim women are capable of being active and dynamic personalities. Besides, this meaning also can be found in the GAP advertisement that illustrates the multi-role played by a hijab Muslim woman, as well as the caption mentioned on the GAP advertisement, "kind-hearted and hard-working". The interpretation is although Muslim women wear hijab and are identical with domestic life, they have the right to express freedom, engage in hobbies or ability that they have, and are even competent in the field of sports.

\section{Myth: Resistance and deconstruction of stereotype.}

Afterward, the tragedy of the WTC 9/11 that sparked the public 18 years ago, the negative stigma against hijab Muslim women still spread out attached to the lives of hijab Muslim women in America. In addition to being a threat, hijab Muslim women are also considered as human beings with many restrictions. The Council on American-Islamic Relations (CAIR) survey in 2004 reported that fifty-one percent of Americans believe that Islam is indeed suppressing women. In its 2006 annual report, CAIR also claimed that the hijab was "a picture of identifying significant discrimination". Similar 
reports in the same year, it was also revealed that 166, or 8.4 percent of 1279 complaints of discrimination, according to CAIR, were triggered by the hijab. ${ }^{24}$

Eber in his article argues that the American public is still largely in the circle of negative assumptions of powerless and uneducated Muslim women. Western perspectives on hijab Muslim women are based on what they see. ${ }^{25}$ According to him, women in the Middle East who wear the hijab, become a symbol of all that is not liked by American society, thus representing the fear they assume to Islam. Furthermore, Nizmi (2015) also explained Hirsi Ali's writings in the Newsweek media which criticized American mass media only to represent Muslim women from ancient stereotypes, the weak and not independent hijab Muslim women. ${ }^{26}$ Now, the role of the media is slowly beginning to help hijab Muslim women in America to voice their existence and deconstruct negative stigmas against them.

Therefore, through the media, especially large and well-known media, hijab Muslim women in America are fighting for their self-esteem to refute and deconstruct the dominant ideological image of Muslim women as helpless human beings. Then, this myth is being reconstructed by American advertising. Nike and GAP present hijab Muslim models that have a strong personality and masculine side. This is a mouthpiece for hijab Muslim women to echo their resistance to the perceptions of American society. The hijab Muslim women are competent beings, have the ability and freedom to express themselves. This is a form of recognition, the presence of advertised Muslim women who try to invite breaking the shackles that have limited the space for women's expression.
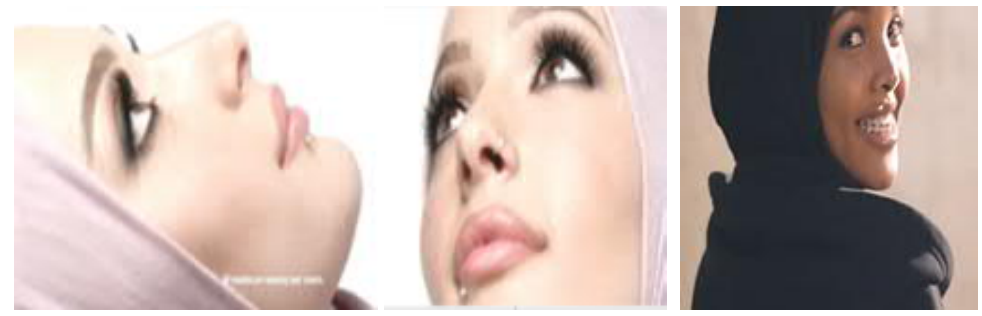

Picture 3: Covergirl and Fenty Beauty

DENOTATION MEANING: as described, the sign in the picture above is the appearance of a hijab Muslim woman. Some pieces of the image are displayed in a zoom shot on the face of a hijab Muslim woman who is using makeup and has a sharp nose and eyes.

CONNOTATION MEANING: Dressing for Muslim women. These two 
American cosmetic products, Covergirl and Fenty Beauty, represent the beauty of a hijab Muslim woman with cosmetic or makeup. Fenty beauty accentuates the lipstick on her model, while Covergirl with lashes and full makeup. Implicitly, the advertisement above illustrate that hijab Muslim women have the space to be beautiful and charming with cosmetic makeup on their faces. They have the same rights as other women do.

Myth: Standardization of beauty (outer beauty). Talking about beauty cannot be separated from the myths surrounding the demands on women, including hijab Muslim women. Being beautiful seems to have become a necessity. A woman can be said to be beautiful if she meets the criteria for the beauty standards adopted by her environment. ${ }^{27}$ For example, the stereotypical image of women as passive, patient, beautiful, and often translated in a narrowespecially-virgin dichotomy in the case of white women. The concept of beauty is a form of cultural institution so that the standard used is based on the dominant groups in society, namely white people until the beauty standards emanate from white people as a form of hegemony practice in American society. Unconsciously, the image of women like this has been internalized in the community, entrenched, and formed a standardization. ${ }^{28}$ Naomi Wolf called it as 'beauty myth', that is standards of beauty that grow and are then fostered by the community. According to Wolf, this myth is a new form and system of repressing women. With such an assumption, in the end, many women are trying to meet the standards and ideals of beauty that are developing in the community. ${ }^{29}$

In the modernization era, the media are very instrumental in shaping the standardization. Sherrie Innes explained that the images formed by the media often experience changes, especially if made by popular media. ${ }^{30}$ Since the massive phenomenon of the beauty world, women are being excited by the emergence of beauty bloggers who wrestle with various kinds of brands and cosmetic tools. This myth is what advertisements rise in their brands, which is the standard of beauty of a hijab Muslim woman. The embodiment of hijab Muslim women in the American advertisement also deconstructs the mainstream beauty industry which has always been dominated by non-hijab and white women. 


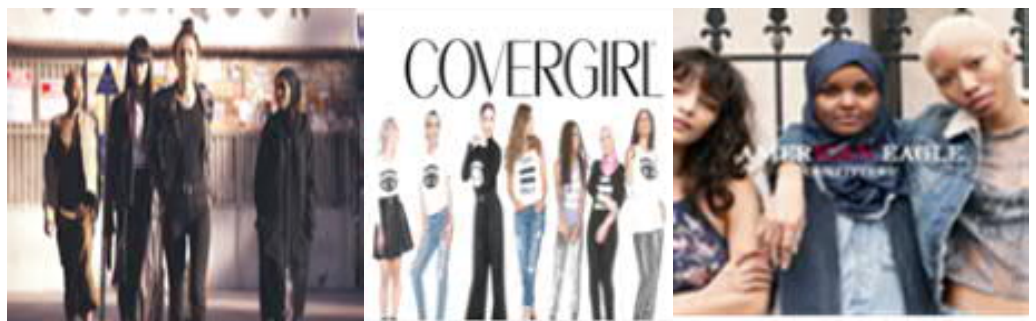

Picture 4: Fenty Beauty, Covergirl, and American Eagle

DENOTATION MEANING: Next, the sign in the picture above is that hijab Muslim women are gathering with other women. they pose and embrace one another. In every picture, there is one woman who wears a hijab. They also have differences in terms of skin color and appearance.

CONNOTATION MEANING: All women are beautiful in their way. The three advertisements above, Fenty Beauty, Covergirl, and American Eagle, collaborate on their models by displaying diverse characteristics. No matter how the race, skin color, hairstyle, body posture, or religious symbols (hijab). Including Muslim women in it. Halima Eden for the Fenty Beauty and American Eagle advertisements came from Somali-African Muslim descent, and Nura Afia for the Covergirl advertisement. By representing the diversity of various models, this advertisement seems to claim that there is no absolute definition of beauty, because all women are beautiful in their ways. Especially for hijab Muslim women who have limited space to express themselves, especially in America

Myth: Egalitarianism. America is a big country where people have white racial hegemony. Besides, some Americans have a problem with islamophobia. This triggers a gap between the African-American population and Muslims who live in the superpower country. A survey conducted by the National Public Radio, the Robert Wood Johnson Foundation, and Harvard T.H Chan (2017) estimates that $92 \%$ of African-American residents believe discrimination against them still exists today. Americans (white men) tend to see AfroAmericans reflecting common perceptions of slaves and blue-collar workers or are at the bottom of the social strata. ${ }^{31}$ In other cases, Muslims also get the same negative stigma and threats in America. Based on a Pew Article Center survey related to the issue of religious discrimination, the Muslim population in America has the most experience of injustice, prejudice, and discrimination. $^{32}$ 
From the social facts above, the value of egalitarianism needs to be echoed in America, for the sake of equal rights, both for the degree of women, black people, and followers of Islam. This ideology of egalitarianism was implied in advertisements. They do this by displaying models, including hijab Muslim women models, which have their unique appearance. This reflects that there is unity indifference.

\section{Religiofication of Commodity in American Brands Adver- tisements.}

Bryan Turner as a sociologist who is involved in religious phenomena once said that modern society is being hit by the globalization of religion which also gave birth to the globalization of piety, the commodification of religion, and spirituality. ${ }^{33}$ This is what the Muslim community face in the world. Islamic popular culture can be observed from various aspects of people's lives. For example, from the lifestyle of hijab Muslim women. They present a variety of Muslim fashion clothes and beauty products that are promoted massively in advertising media. Along with the rise of Muslim women consumers, do not be surprised if many market companies that claim that their products are Muslim friendly.

This phenomenon is familiarly called the commodification of religion. In the discussion about the commodification that accompanies religious appendages in it, Lukens-Bull comes with his thoughts in 'the Commodification of Religion' and the 'Religification of Commodities'. ${ }^{34}$ That there are two processes of 'religiofication' of commodities and the commoditization of religion - which essentially describes two variations of the same process. The first process begins with a product and infuse it with meaning. By investing in commodities with an ideological meaning, namely religion, capitalists can make their products more than just a product of commerce. They becomea way to show national loyalty to consumers, maintain faith, and fulfill ritual obligations. Meanwhile, the second process begins with meaning and tries to express it in material form. Manufacturers and sellers of these products seek to express pre-existing consumer sentiment to create the desired product. A significant observation is that the commodification of religion involves the production of commodities which contain religious meanings and the inclusion of religious (or ideological) meanings into commodities. Significantly, this is not so new, but only an extension of the standard practice of 
product creation, advertising, and branding. Within this context, the American advertisement products are considered as an embodiment of the first process, a product that is infused with an ideological meaning (religion). This is seen from the form of marketing products that are not Islamic nuances at all and the trace of their product promotion also has never presented Muslims before, especially hijab Muslim women. This can be seen from the following online media:
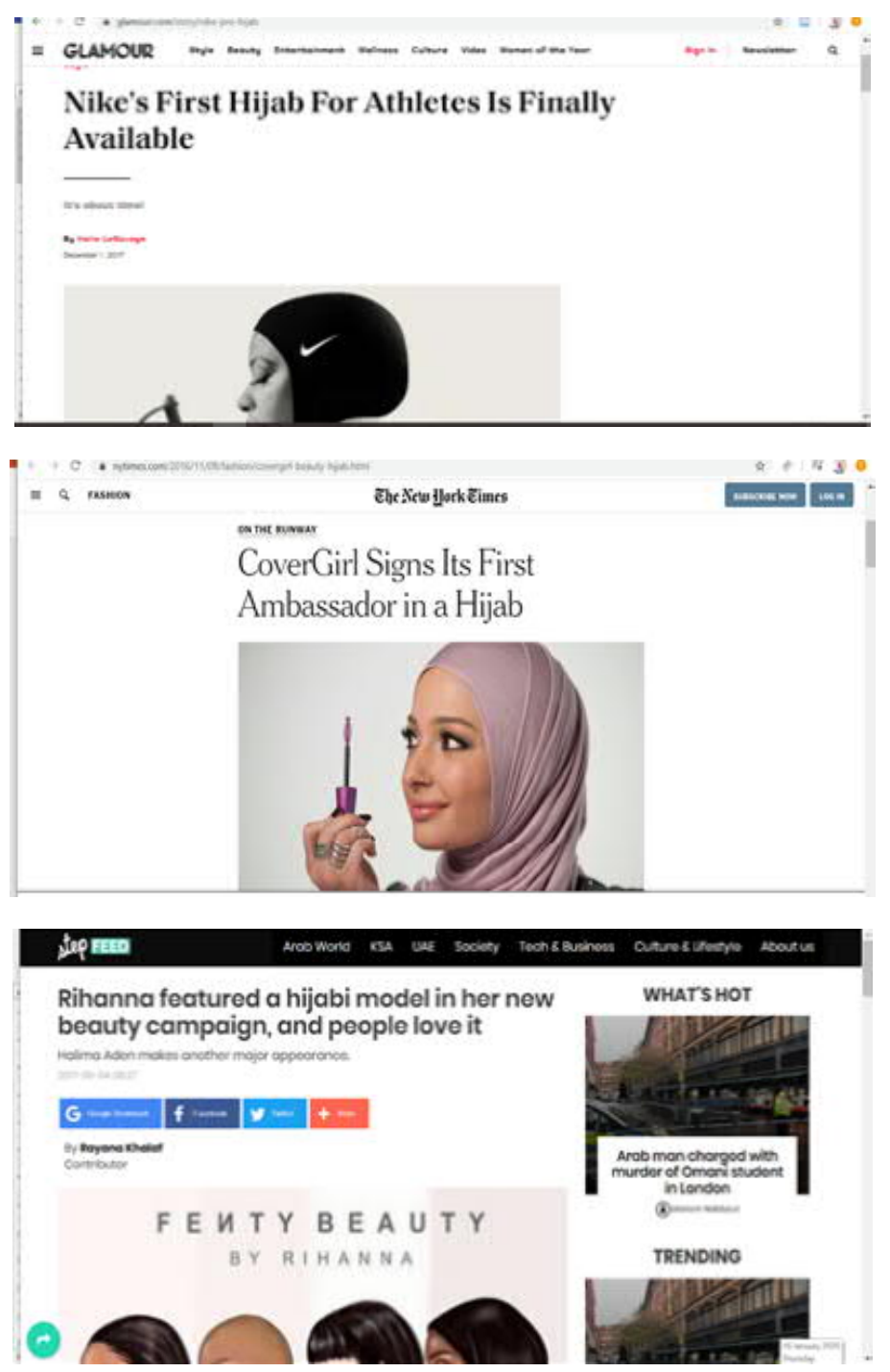

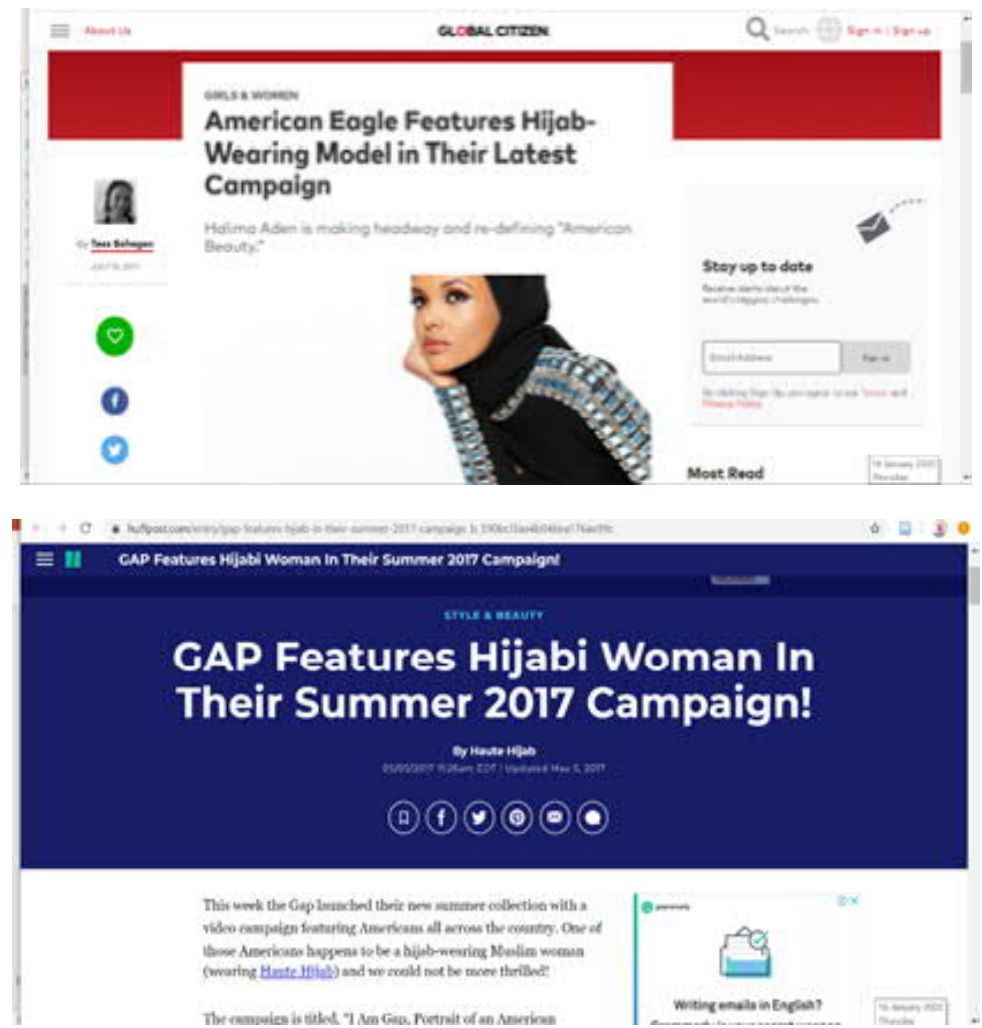

The online news media come from various western sites. From the five news sources above, it can be concluded that previously they had never touched the Islamic symbols or attributes in their marketing. Thus, this is the first time for Nike, Fenty Beauty, Covergirl, American Eagle, and GAP to display and use hijab Muslim women in their product promotion campaigns, and even some of them release hijab products. Given that the five products are original products manufactured and centered in America (non-Muslims), this certainly ensures their products are not specifically intended for the Muslim community.

This fact indicates a process referred by Lukens-Bull with the religiofication of meaning (religion) implanted or infused in a product, or familiarly called 'Islamization of product'. It can be simply understood as the inclusion of religious values into a commodity product. If people look at the five American advertisement products that feature hijab Muslim women and recruit them as brand ambassadors, of course, this only seems to be a gateway to enter a large market opportunity, namely the commercialization of Islam - 
symbols become tangible commodities that can be traded to pursue benefits of consumers of the Muslim community. ${ }^{35}$ Moreover, marketing activities are carried out along with the explosion of demand (needs) from Muslim women around the world.

However, the existence of hijab Muslim women American advertisements is not just a phenomenon for reaching the target market or getting money. If Noorhaidi Hasan sees the fact of the commodification of religion in Indonesia as a form of $d a$ 'wah revitalization and more modern, progressive, and inclusive religious practice, ${ }^{36}$ while it is not the same as what happens in a country where Muslim communities are a minority or even oppressed.

A little to discuss what the previous author has explained previously that America is a country with the problem of Islamophobia. However, this Superpower cannot escape the influence of the development of Islamic popular culture, one of which is the lifestyle of Muslim women. It can be observed from the beginning of emerging forms of Islamic fashion shows in America, there are even specifically for Muslim fashion shows called USA Islamic Fashion Week. This was also followed by Nike, Fenty Beauty, Covergirl, American Eagle, and GAP by following the current market opportunities of hijab Muslim women's lifestyles.

Indeed, this fact seems like commercialized, yet it implies a form of resistance. This can be seen from the way these advertisements represent hijab Muslim women, as explained earlier. These advertisements represent the dominant hijab model with the interpretation of freedom, equality, and competence of a hijab Muslim woman. The fifth step of American advertisements is considered to be brave amid the rise of anti-Muslim right-wing in the United States and Europe. Additionally, these five product brands come from a country that is now led by a president who is famous for hating Islam and Muslims, Donald Trump. Of course, there is a process of adaptation in this great American product with the country where they take shelter.

Interestingly, this phenomenon is a paradox. These American advertisements are a resistance to the stigma of society, but they are globally accepted. The resistance in question is a form of resistance to stereotypes that are formed also globally. Hijab Muslim women in American advertisements are a response and reaction to the stigma of society which considers that hijab Muslim women are restricted and oppressed human beings. 


\section{CONCLUSION}

In summary, despite being a minority and shadowed by negative stereotypes, these hijab Muslim women try to prove and express that they can still excel in their respective fields. They can show that despite their limitations, they were able to fight against the slanted judgments they received every day. Given the threats they often receive from the public sphere, Muslim women in America end up struggling through advertising media. They use official sources, such as those owned by giant and well-known media. They did to refute the image of the dominant ideology of Muslim women as being weak.

Referring to what Gramsci said that mass media as space for all ideologies. ${ }^{37}$ It means that the media can be a tool of authority, legitimacy, as well as control of the public sphere. In this case, however, the media can also be an instrument of the struggle of the oppressed to build a counter-culture and ideology. The picture in the American advertisement is not such a new thing where there is a process of infusing religious symbols in a product, namely the commodification of religion, precisely the 'religiofication' of commodities. As stated by Luckens-Bull and other religious commodity theories, it means to use the religious symbol to become a commodity that can be traded and obtain profits (business interests). Meanwhile, Noorhaidi said the religious commodity is a framework of the moral order of society through objectification and systemization of religious values and practices. Different from others, the religiofication of commodities by using of hijab Muslim women in American advertisements is not only as making-money or commoditization of religion, but this is a form of resistance or borrowing the term Arlene Elowe Macleod as a form of accommodating protest. They kind of want to protest and deconstruct the stereotype that arises in the public, instead they exist in media and express what they want to reconstruct. As a result, their existence in the advertising frame is an underground movement (underground movement) which as a form of their resistance to negative stigmas that are assumed and internalized in American society. Through advertising media, they have space to express the identity, ability, and essence of egalitarianism.

\section{ENDNOTES}

1 William L Rivers, Theodore Peterson, and Jay Walbourne Jensen, The Mass Media and Modern Society (San Francisco: Rinehart Press, 1971).

2 Andi Abdul Muis, Komunikasi Islami, cet. 1 (PT. Rosdakarya Remaja, 2001). 
3 Dendy Triadi Bharata Addy Sukma, Ayo Bikin Iklan: Memahami Teori \& Praktek Iklan Media Lini Bawah (Elex Media Komputindo, t.t.), 10.

4 David Chaney, Life Styles/ : Sebuah Pengantar Komprehensif (Jalasutra, 2008), 19.

5 Morissan, Periklanan: komunikasi pemasaran terpadu / Morissan) (Jakarta: Kencana, 2015), 23.

6 Louis ALTHUSSER, Tentang Ideologi: Marxisme Strukturalis, Psikoanalisis, Cultural Studies\# Louis Althusser, Cet.3. (Jala, n.d.), 20.

7 Media Inquiries, "A New Estimate of U.S. Muslim Population," Pew Article Center (blog), diakses 22 Agustus 2019, https://www.pewarticle.org/fact-tank/ 2018/01/03/new-estimates-show-u-s-muslim-population-continues-to-grow/.

8 "Busana Muslim Indonesia Berkiprah di New York Couture Fashion Week," VOA Indonesia, diakses 7 September 2019, https://www.voaindonesia.com/a/ busana-muslim-indonesia-berkiprah-di-new-york-couture-fashion-week/ 2979530.html.

9 Roland Barthes, Elements of Semiology 1st Edition, 1977,

10 Roland Barthes dan Annette Lavers, Mythologies (Farrar, Straus and Giroux, 1972),

11 Daniel Chandler, Semiotics: the basics, 2nd ed, Basics (Routledge (Firm) (London/ ; New York: Routledge, 2007).

12 Chandler.

13 Media Inquiries, "Many Americans See Religious Discrimination in U.S. - Especially against Muslims," Pew Research Center, n.d., accessed December 15, 2019, https://www.pewresearch.org/fact-tank/2019/05/17/many-americans-see-religious-discrimination-in-u-s-especially-against-muslims/.

14 Wan Ulfa Nur Zuhra, "Serangan Anti-Islam di Amerika dalam Statistik," tirto.id, accessed March 5, 2020, https://tirto.id/serangan-anti-islam-di-amerika-dalamstatistik-b5HB.

15 Jim Everett dkk., "Covered in stigma? The impact of differing levels of Islamic head-covering on explicit and implicit biases toward Muslim women," Journal of Applied Social Psychology 45 (1 Agustus 2014): 90-104.

${ }^{16}$ Eman Abdelhadi, "Religiosity and Muslim Women's Employment in the United States," Socius 3 (January 1, 2017): 2378023117729969.

17 Eman Abdelhadi dan Paula England, "Do Values Explain the Low Employment Levels of Muslim Women around the World? A within- and betweenCountry Analysis,” The British Journal of Sociology 70, no. 4 (2019): 1510-38.

18 Carol A. Stabile dan Deepa Kumar, "Un hijabing Imperialism: Media, Gender and the War on Afghanistan," Media, Culture $\mathcal{E}$ Society 27, no. 5 (1 September 2005): 765-82,

19 Jasmin Zine, "Muslim women and the politics of representation.," Journal of Islamic Social Sciences 19, no. 04 (2002): 1-22.

20 Linda Steet, Hijabs and Daggers: A Century of National Geographic's Representation of the Arab World, 2000.

${ }^{21}$ Fauzia Ahmad, "Still 'in Progress?' - Methodological Dilemmas, Tensions and 
Contradictions in Theorizing South Asian Muslim Women,” 2003, 43-65; Sajad Kabgani, "The Representation of Muslim Women in Non-Islamic Media: A Critical DisoourseAnalysisStudyon Guardian," International Joumal of Women's Research 2, no. 1 (May 1, 2013): 57-78; Muhammad Khan and Sadaf Zahra, "Portrayal of Muslim Women by Western Print Media: A Textual Analysis in Feministic \& Orientalist Perspective" 17 (September 19, 2016): 41-57; Amanda Pichette, "Representations of Muslim Women in the Quebec News Print Media" (masters, Concordia University, 2012), accessed December 14, 2019.

22 Michelle Byng, "Symbolically Muslim: Media, Hijab, and the West," Critical Sociology 36 (February 1, 2010): 109-129.

23 Elfriede Fürsich, "Media and the Representation of Others," International Social Science Journal 61, no. 199 (2010): 113-30.

24 Council on American-Islamic Relations, "AMERICAN PUBLIC OPINION ABOUT ISLAM AND MUSLIMS,” 2006, : www.cair.com.

25 Paula Holmes-Eber dkk., Conceptions and Misconceptions of Women in the Middle East (Seattle: UWTV, 2001), 43.

26 Yusnarida Eka Nizmi, "American View of Muslim Women after Eleven September 2001 Post-Attack," Jurnal Kajian Politik Dan Masalah Pembangunan VOL. 11 No. 01 (2015): 1623-1632.

27 Sarah Santi, "Perempuan Dalam Iklan: Otonomi Atas Tubuh Atau Komoditi?," Jurnal Komunikologi (Ilmu Komunikasi) 1, no. 1 (2004),

28 Carolyn Kitch, "Changing Theoretical Perspectives on Women's Media Images: The Emergence of Patterns in a New Area of Historical Scholarship:, Journalism $\mathcal{E}$ Mass Communication Quarterly, 25 Juni 2016.

29 Naomi Wolf, The Beauty Myth: How Images of Beauty Are Used against Women (New York: W. Morrow, 1991).

30 Sherrie A. Inness, Tough Girls/: Women Warriors and Wonder Women in Popular Culture (University of Pennsylvania Press, 1999), 56.

31 Martin N. Marger, Race and Ethnic Relations: American and Global Perspectives, 8 edition (Belmont, CA: Wadsworth Publishing, 2008).

32 NW, Suite 800Washington, and Inquiries, "Many Americans See Religious Discrimination in U.S. - Especially against Muslims."

33 Bryan S. Turner, Sosiologi Agama (Pustaka Pelajar, 2013), 153.

34 Patta Kitiarsa, Religious Commodifications in Asia: Marketing Gods (Routledge Studies in Asian Religion and Philosophy), 1 ed., 2008, 233.

35 Greg Fealy, Sally White, dan Institute of Southeast Asian Studies, Expressing Islam: Religious Life and Politics in Indonesia. (Singapore: Institute of Southeast Asian Studies (ISEAS), 2008), 16-17.

36 Noorhaidi Hasan, "The Making of Public Islam: Piety, Agency, and Commodification on the Landscape of the Indonesian Public Sphere," Contemporary Islam 3, no. 3 (24 Oktober 2009): 242.

37 Roger Simon, Gagasan-Gagasan Politik Gramsci (Pustaka Pelajar, 2004). 


\section{REFERENCE}

Abdelhadi, Eman, dan Paula England. 2019. "Do Values Explain the Low Employment Levels of Muslim Women around the World? A within- and betweenCountry Analysis." The British Journal of Sociology 70, no. 4.

Ahmad, Fauzia. 2003. "Still 'in Progress?' - Methodological Dilemmas, Tensions and Contradictions in Theorizing South Asian Muslim Women,".

Barthes, Roland. Elements of Semiology 1st Edition, 1977. http://gen.lib.rus.ec/book/ index.php?md5=17A86C819E4F6FDBCE177D2569552FE5.

Barthes, Roland, dan Annette Lavers.1972. Mythologies. Farrar, Straus and Giroux, http://gen.lib.rus.ec/book/index.php?md5=FDFDF765DC151B05499E8789C37D6FBC.

Bharata, Dendy Triadi, Addy Sukma. Ayo Bikin Iklan: Memahami Teori EO Praktek Iklan Media Lini Bawah. Elex Media Komputindo, t.t.

VOA Indonesia. "Busana Muslim Indonesia Berkiprah di New York Couture Fashion Week.” [internet].[diakses 7 September 2019]. Tersedia di https:// www.voaindonesia.com/a/busana-muslim-indonesia-berkiprah-di-new-york-couture-fashion-week/2979530.html.

Byng, Michelle. 2010. "Symbolically Muslim: Media, Hijab, and the West." Critical Sociology 36.

Chandler, Daniel. 2007. Semiotics: the basics. 2nd ed. Basics (Routledge (Firm). London/ ; New York: Routledge.

Council on American-Islamic Relations. 2006. "AMERICAN PUBLIC OPINION ABOUT ISLAM AND MUSLIMS,”. [internet]. Tersedia di : www.cair.com.

Edward S. Herman, Noam Chomsky. 2010. Manufacturing Consent: The Political Economy of The Mass Media. Pantheon Books,.

Everett, Jim, Fabian Schellhaas, Brian Earp, Victoria Ando, Jessica Memarzia, Cesare Parise, Benjamin Fell, dan Miles Hewstone. 2014. "Covered in stigma? The impact of differing levels of Islamic head-covering on explicit and implicit biases toward Muslim women.” Journal of Applied Social Psychology Vol 45. No.1

Fealy, Greg, Sally White,. 2008. dan Institute of Southeast Asian Studies. Expressing Islam: Religious Life and Politics in Indonesia. Singapore: Institute of Southeast Asian Studies (ISEAS),

Fürsich, Elfriede. 2010. "Media and the Representation of Others." International Social Science Journal Vol 61, no. 199

Hasan, Noorhaidi. 2009. "The Making of Public Islam: Piety, Agency, and Commodification on the Landscape of the Indonesian Public Sphere." Contemporary Islam "Vol 3, no. 3

Holmes-Eber, Paula, Christine Ruiz, Wash. 2001.UWTV (Television station/ : Seattle, dan Henry M. Jackson School of International Studies. Conceptions and Misconceptions of Women in the Middle East. Seattle: UWTV, [internet]. Tersedia pada: http://www.articlechannel.org/program/displayevent.asp?rid=1207.

Inness, Sherrie A. Tough Girls: Women Warriors and Wonder Women in Popular Culture, 1999.

Kabgani, Sajad .2013. "The Representation of Muslim Women in Non-Islamic 
Media: A Critical Discourse Analysis Study on Guardian.” International Journal of Women's Article Vol. 2, no. 1.

Khan, Muhammad, dan Sadaf Zahra. 2016. "Portrayal of Muslim Women by Western Print Media: A Textual Analysis in Feministic \& Orientalist Perspective” 17.

Kitch, Carolyn. 2016. "Changing Theoretical Perspectives on Women's Media Images: The Emergence of Patterns in a New Area of Historical Scholarship:" Journalism Eु Mass Communication Quarterly. Tersedia pada: https://doi.org/ 10.1177/107769909707400303.

Kitiarsa, Patta. 2008. Religious Commodifications in Asia: Marketing Gods (Routledge Studies in Asian Religion and Philosophy). 1 ed.

Marger, Martin N. 2008. Race and Ethnic Relations: American and Global Perspectives. 8 edition. Belmont, CA: Wadsworth Publishing,.

Morissan. 2015. Periklanan: komunikasi pemasaran terpadu / Morissan). Jakarta: Kencana.

Muis, Andi Abdul. 2001. Komunikasi Islami. Cet. 1. PT. Rosdakarya Remaja.

Muttaqin, Farid. 2001. Teroris serang Islam/ : babak baru benturan barat Islam/Editor: Sukidi. Pustaka Hidayah,.

Nizmi, Yusnarida Eka. 2001. "Pandangan Amerika Terhadap Perempuan Muslim Pasca Serangan Sebelas September.” POLITIK 11, no. 1 (20 Mei 2015). http:/ /journal.unas.ac.id/politik/article/view/122.

NW, 1615 L. St, Suite 800Washington, dan DC 20036USA202-419-4300 | Main202-857-8562 | Fax202-419-4372 | Media Inquiries. "A New Estimate of U.S. Muslim Population.” Pew Article Center (blog). Diakses 22 Agustus 2019. Tersedia pada: https://www.pewarticle.org/fact-tank/2018/01/03/new-estimates-show-u-s-muslim-population-continues-to-grow/.

Pichette, Amanda. 2012. "Representations of Muslim Women in the Quebec News Print Media.” Masters, Concordia University.

Rivers, William L, Theodore Peterson, dan Jay Walbourne Jensen. 1971.The Mass Media and Modern Society. San Francisco: Rinehart Press.

Santi, Sarah. 2004. "Perempuan Dalam Iklan: Otonomi Atas Tubuh Atau Komoditi?” Jurnal Komunikologi (Ilmu Komunikasi) Vol 1, no. 1.

Shoemaker, Pamela J., dan Stephen D. Reese. 2013. Mediating the Message in the 21st Century: A Media Sociology Perspective. 3 ed. Routledge,.

Simon, Roger, Gagasan-Gagasan Politik Gramsci (Pustaka Pelajar, 2004).

Stabile, Carol A., dan Deepa Kumar. "Unhijabing Imperialism: Media, Gender and the War on Afghanistan.” Media, Culture Eु Society. Vol 27, no. 5.

Steet, Linda. 2000. Hijabs and Daggers: A Century of National Geographic's Representation of the Arab World,

Turner, Bryan S. 2013. Sosiologi Agama. Pustaka Pelajar.

Wolf, Naomi. 1991.The Beauty Myth: How Images of Beauty Are Used against Women. New York: W. Morrow,

Zine, Jasmin. 2002. "Muslim women and the politics of representation." Journal of Islamic Social Sciences 19, no. 04. 
